\title{
Recent volume and area changes of Kaskawulsh Glacier, Yukon, Canada
}

\author{
Norah FOY, ${ }^{1}$ Luke COPLAND, ${ }^{1}$ Christian ZDANOWICZ, ${ }^{2}$ Mike DEMUTH, ${ }^{2}$ \\ Chris HOPKINSON ${ }^{3}$ \\ ${ }^{1}$ Department of Geography, University of Ottawa, Ottawa, Ontario K1N 6N5, Canada \\ E-mail: luke.copland@uottawa.ca \\ ${ }^{2}$ Geological Survey of Canada, Natural Resources Canada, Ottawa, Ontario K1A OE8, Canada \\ ${ }^{3}$ Applied Geomatics Research Group, Centre of Geographic Sciences, Middleton, Nova Scotia, Canada
}

\begin{abstract}
Recent surface elevation changes of Kaskawulsh Glacier, Yukon, Canada, are quantified by comparing an air-photo derived DEM from 1977 and airborne lidar measurements from 1995, 2000 and 2007. Surface-area changes are assessed using historical aerial photography from 1956 and satellite imagery from 1977 to 2007 . Combined, these measurements provide some of the first detailed records of volume change of a large Yukon glacier. Between 1977 and 2007, Kaskawulsh Glacier underwent a decrease in area of $1.53 \%$ and a decrease in volume of $3.27-5.94 \mathrm{~km}^{3}$ w.e.). The terminus also retreated by $655 \mathrm{~m}$ over the period 1956-2007. There was relatively minor volume change over the period 1977$95\left(<+0.01 \mathrm{~km}^{3}\right.$ w.e. $\left.\mathrm{a}^{-1}\right)$, while over the periods 1995-2000 and 2000-07 volume losses occurred at a relatively constant rate of -0.51 and $-0.50 \mathrm{~km}^{3} \mathrm{a}^{-1}$ w.e., respectively. Since 1995 , thinning has been prominent throughout the ablation zone, while relative stability and even slight thickening has occurred in the accumulation zone. These findings are similar to those recently observed at other nearby Alaskan glaciers.
\end{abstract}

\section{INTRODUCTION}

Glaciers in the southwest Yukon and Alaska represent $\sim 14 \%$ of Earth's glaciated area outside Greenland and Antarctica (ACIA, 2004), and like most mountain glaciers, they are generally thinning and retreating. Arendt and others (2002) measured the average rate of thinning of glaciers in this area between the mid-1950s and mid-1990s to be $\sim 0.52 \mathrm{~m} \mathrm{a}^{-1}$. Between the mid-1990s and 2001, the average rate of thinning increased to $\sim 1.8 \mathrm{~m} \mathrm{a}^{-1}$. This change amounts to $96 \pm 35 \mathrm{~km}^{3} \mathrm{a}^{-1}$ of water loss, which raises global sea level by $0.27 \pm 0.10 \mathrm{~mm} \mathrm{a}^{-1}$, or $\sim 9 \%$ of the total observed rise over the past 50 years (Arendt and others, 2002). Further altimeter-based measurements showed that losses in this region between the 1950s and 2002 may be greater by a factor of two (Arendt and others, 2006; Larsen and others, 2007). These values are closely corroborated by Gravity Recovery and Climate Experiment (GRACE) data which indicate that glaciers in the Gulf of Alaska region lost mass at an average rate of $101 \pm 22 \mathrm{~km}^{3} \mathrm{a}^{-1}$ between 2002 and 2005 (Chen and others, 2006). Using mascon (mass concentration) corrections for GRACE, Luthcke and others (2008) determined that glaciers in the Gulf of Alaska lost volume at a rate of $84 \pm 5 \mathrm{~km}^{3} \mathrm{a}^{-1}$ between 2003 and 2006. Arendt and others (2008) narrowed GRACE mascon calculations to the St Elias Mountains and by combining these data with laser altimetry measurements, losses were calculated to be between $20.6 \pm 3.0$ and $21.1 \pm 3.8 \mathrm{~km}^{3} \mathrm{a}^{-1}$, a rate that had been approximately steady for several decades.

Recently, temperatures in the southwest Yukon have been increasing, with a warming of $2.0^{\circ} \mathrm{C}$ between 1948 and 2008 (Environment Canada, http://www.ec.gc.ca/adsc$\mathrm{cmda} /$ default.asp?lang=en $\& \mathrm{n}=4 \mathrm{CC} 724 \mathrm{DA}-1)$. Warming is predicted to continue, with mean annual temperature in the southwest Yukon expected to increase by $\sim 3-3.5^{\circ} \mathrm{C}$ by 2099 (Solomon and others, 2007). As a consequence of this temperature increase and a projected intensification of the Aleutian low, average annual precipitation in this region is expected to increase by up to $20 \%$ by 2099 , with up to a $30 \%$ increase in winter (Solomon and others, 2007). There is therefore a need for improved understanding of how climate change is affecting glaciers in the southwest Yukon, particularly as most existing studies focus on the Alaskan side of the St Elias Mountains. This study aims to address this need through calculations of changes in the volume of Kaskawulsh Glacier.

Kaskawulsh Glacier is a large, temperate valley glacier located within Kluane National Park in the St Elias Mountains $\left(60^{\circ} 43^{\prime} \mathrm{N}, 138^{\circ} 51^{\prime} \mathrm{W}\right.$; Fig. 1$)$. It flows generally northeast, is $\sim 70 \mathrm{~km}$ long and is not known to surge (although some tributaries do). The extensive Kluane Icefields, located to the west of the glacier, supply ice to the north and central arms of Kaskawulsh Glacier. The South Arm of the glacier is supplied by a catchment basin located to the south and southeast. The terminus is currently at $\sim 830$ ma.s.l., and since 1836 it has been generally retreating, with increased wastage since 1980 (Borns and Goldthwait, 1966; Wiles and others, 2002; Reyes and others, 2006).

\section{METHODS}

Changes of Kaskawulsh Glacier are examined via changes in surface height and extent, with this information combined to quantify changes in water equivalent volume. Elevation data were obtained for four periods between 1977 and 2007 from stereo aerial photography and airborne laser altimetry (Table 1). Glacier extent was obtained for nine periods between 1956 and 2007 from aerial photographs and satellite imagery (Table 1). All data were projected in Universal Transverse Mercator (UTM) zone 7N (NAD83 datum, GRS80 ellipsoid) in ESRI ArcGIS 9.2 for analysis. 


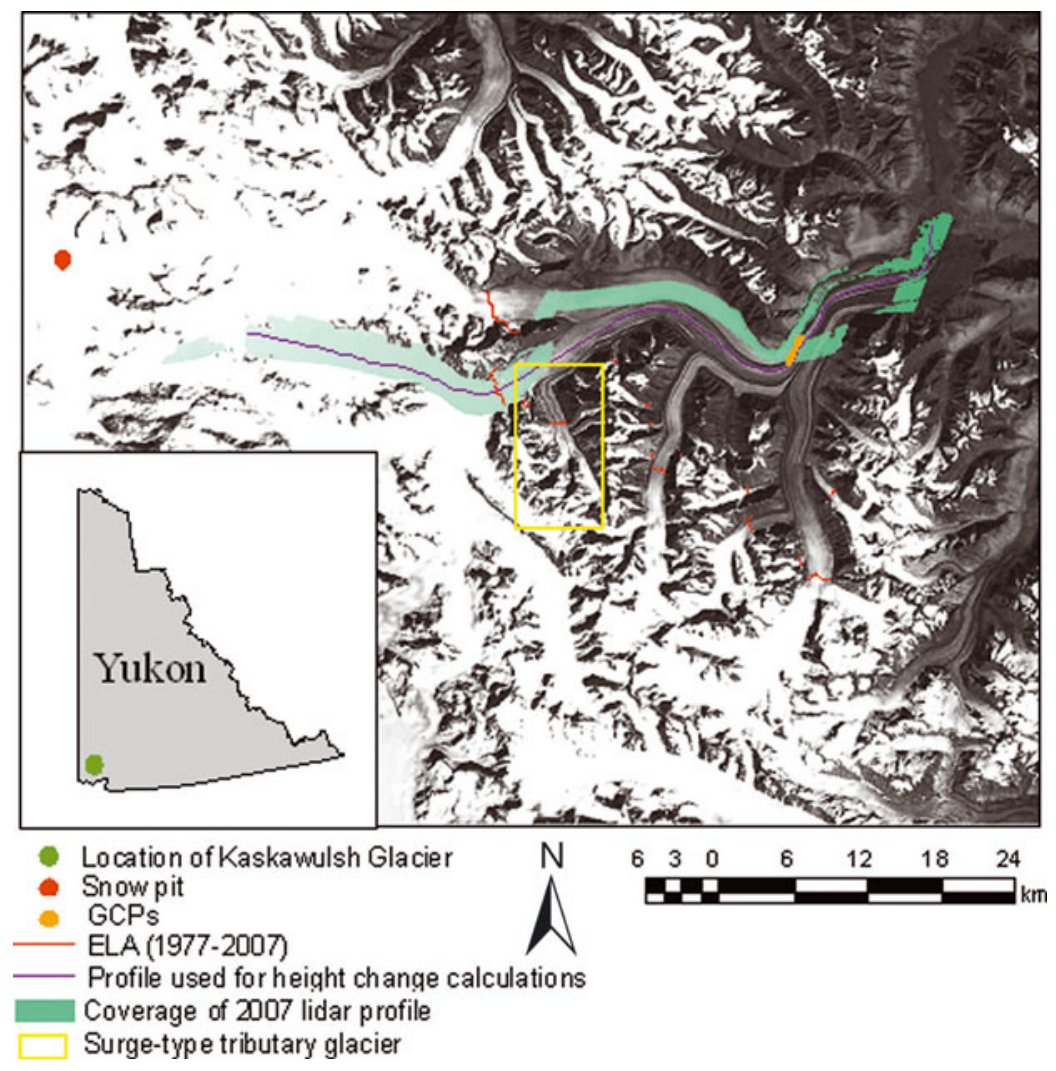

Fig. 1. Kaskawulsh Glacier (base image: Landsat 2, 3 September 1977).

\subsection{Elevation data}

The 1977 surface consisted of a Canadian Digital Elevation Data (CDED) digital elevation model (DEM) derived from stereo matching of aerial photographs collected in 1976 and 1977. Cumulative vertical errors in the CDED DEM are assumed to be $\pm 15 \mathrm{~m}$ below the equilibrium-line altitude
(ELA), and $\pm 30-45 \mathrm{~m}$ above the ELA due to difficulties with matching surface features in snow-covered terrain (Echelmeyer and others, 1996; Larsen and others, 2007). One area of anomalously steep surface slope was observed in this dataset in the accumulation area, and when this DEM is compared to all other elevation data a prominent depression

Table 1. Elevation and area data used in this study

\begin{tabular}{|c|c|c|c|c|c|c|}
\hline Type & Source & Projection & Horizontal datum & Vertical datum & Date(s) of acquisition & Resolution \\
\hline \multicolumn{7}{|l|}{ Elevation data } \\
\hline DEM mosaic & CDED & GCS & NAD83 & CVGD28 & $1976 / 77$ & $23 \mathrm{~m}$ \\
\hline Non-scanning lidar profile & $\begin{array}{c}\text { University of Alaska } \\
\text { Fairbanks }\end{array}$ & UTM 7N & NAD83 & GRS80 & $\begin{array}{l}20 \text { May } 1995 ; \\
29 \text { May } 2000\end{array}$ & $0.18 \mathrm{~m}$ \\
\hline Scanning lidar profile & This study & UTM 7N & NAD83 CSRS & GRS80 & 12 Aug 2007 & $0.18 \mathrm{~m}$ \\
\hline \multicolumn{7}{|l|}{ Area data } \\
\hline Air photo mosaic & $\begin{array}{l}\text { Air photos (scale } \\
1: 70000), \text { NAPL }\end{array}$ & UTM 7N & NAD83 & $\mathrm{n} / \mathrm{a}$ & Summer 1956 & $10 \mathrm{~m}$ \\
\hline Satellite image & Landsat 2 (GLCF) & UTM 7N & NAD83 & $\mathrm{n} / \mathrm{a}$ & 3 Sep 1977 & $60 \mathrm{~m}$ \\
\hline Satellite image & Landsat 5 (GLCF) & UTM 7N & NAD83 & $\mathrm{n} / \mathrm{a}$ & $\begin{array}{l}29 \text { Oct 1986; } \\
12 \text { Aug 1990; } \\
16 \text { Aug 1994; } \\
19 \text { Jul } 2001\end{array}$ & $30 \mathrm{~m}$ \\
\hline Satellite image & Landsat 7 (USGS) & UTM 7N & NAD83 & $\mathrm{n} / \mathrm{a}$ & $\begin{array}{l}9 \text { Jun 2007; } \\
12 \text { Aug 2007; } \\
28 \text { Aug 2007 }\end{array}$ & $15 \mathrm{~m}$ \\
\hline Satellite image & ASTER (LP DAAC) & UTM 7N & NAD83 & $\mathrm{n} / \mathrm{a}$ & $\begin{array}{l}10 \text { Jun } 2001 ; \\
20 \text { May } 2003 ; \\
2 \text { Mar } 2006\end{array}$ & $15 \mathrm{~m}$ \\
\hline Satellite image & SPOT 5 (SPIRIT) & UTM 7N & NAD83 & $\mathrm{n} / \mathrm{a}$ & 3 Sep 2007 & $5 \mathrm{~m}$ \\
\hline
\end{tabular}

Note: CDED = Canadian Digital Elevation Data, Natural Resources Canada; NAPL = National Air Photo Library, Natural Resources Canada; GLCF = Global Land Cover Facility, University of Maryland; LP DAAC = Land Processes Distributed Active Archive Center, United States Geological Survey; SPIRIT = SPOT 5 stereoscopic survey of Polar Ice: Reference Images and Topographies, Université de Toulouse. 
is observed, the shape and size of which suggested that a low-level cloud may have been interpreted locally as the glacier surface. This region was removed from all analyses. Additionally, a tributary glacier on the central arm of Kaskawulsh Glacier surged between 1977 and 1994 (Fig. 1), which resulted in a rapid advance of its terminus by $\sim 2 \mathrm{~km}$ and a local gain in surface height. Portions of surface profiles affected by this surge event were removed from analysis as their local changes in surface height are controlled by surge dynamics rather than glacier mass balance.

Airborne laser altimetry (light detection and ranging; lidar) is currently one of the best methods to monitor the mass balance of glaciers in mountainous areas (Echelmeyer and others, 1996), as current technology allows small changes to be quantified over large featureless areas where derivation of topographic information from stereo imagery can be unreliable (Hopkinson and others, 2001; Hopkinson and Demuth, 2006). Surface elevations for 1995 and 2000 were derived from flight-lines undertaken by the University of Alaska Fairbanks with a non-scanning lidar mounted beneath a Piper PA12 aircraft flying at $\sim 100-500 \mathrm{~m}$ above the glacier surface. This system only samples the points directly beneath the aircraft, with a surveyed area (laser footprint) of $0.18 \mathrm{~m}$ at a flight altitude of $100 \mathrm{~m}$ and measurements collected every $\sim 1.2 \mathrm{~m}$ along track (Echelmeyer and others, 1996). Positioning was provided with a differential GPS (dGPS). The range accuracy of this laser altimeter is $\sim 0.3 \mathrm{~m}$ (Echelmeyer and others, 1996; Arendt and others, 2002), although errors increase with increasing slope.

Surface elevations in 2007 were determined using an airborne scanning laser altimeter operated by C-CLEAR (Canadian Consortium for Lidar Environmental Applications Research). The sensor used was an Optech Inc. airborne laser terrain mapper (ALTM) model 3100 flown on a Twin Otter at $400-1500 \mathrm{~m}$ above the glacier surface. The data were collected at a pulse repetition frequency of $33 \mathrm{kHz}$ across a swath of $\pm 25^{\circ}$ from nadir, which resulted in cross-track and along-track point spacing of 2-10 $\mathrm{m}$ at the glacier surface. All ground points were referenced to the aircraft trajectory, which was determined from an inertial measurement unit and dGPS mounted inside the Twin Otter. The dGPS data were differentially corrected to a base station located at Kluane Lake Research Station $(<30 \mathrm{~km}$ from the glacier terminus). The ALTM 3100 was calibrated in Calgary prior to and following the Kluane mission. Elevation root-meansquare error (RMSE) across the full $25^{\circ}$ swath was $<15 \mathrm{~cm}$ when flown at $1500 \mathrm{~m}$ a.g.I. For Kaskawulsh Glacier survey configuration, system-related errors are anticipated to be within $0.5 \mathrm{~m}$ vertically and $2 \mathrm{~m}$ horizontally (Goulden and Hopkinson, 2010). Coverage of the main glacier was achieved by surveying two adjacent flight-lines in an upand down-glacier direction. To best match the coarsely spaced 1995/2000 lidar data, a DEM was created using a nearest-neighbour routine, and the data were resampled to $70 \mathrm{~m}$ grid spacing. One of the 2007 flight-lines deviated moderately from the 1995/2000 lidar lines over the glacier terminus (below $1353 \mathrm{~m}$ ), and these non-overlapping regions could not be analyzed for change.

\subsection{Areal data}

Partial coverage of Kaskawulsh Glacier for 1956 was provided by mosaicking 11 aerial photographs, each encompassing an area of $\sim 15.2 \times 15.2 \mathrm{~km}^{2}$. These photos covered the terminus and central arm of the glacier almost up to the equilibrium line, together with the entire South Arm. The images were acquired during the summer at flight altitudes of $3400-4900 \mathrm{~m}$, and were scanned at $150 \mathrm{dpi}$, which yielded a resolution of $10 \mathrm{~m}$.

In the recent period, Landsat images were acquired for 1977, 1986, 1990, 1994, 2001 and 2007 (Table 1). Images from 2007 have bands with missing data due to failure of the Landsat 7 scan-line corrector. Complete 2007 coverage was therefore provided by supplementing a 9 June 2007 image with a 12 August 2007 image in the accumulation area and a 28 August 2007 image over the terminus. Advanced Spaceborne Thermal Emission and Reflection Radiometer (ASTER) scenes covering the entirety of Kaskawulsh Glacier were also used from 2001 and 2006, with the 2001 scene used to digitize the glacier terminus (except where there was cloud over the eastern terminus, where Landsat was used instead). Finally, a SPOT-5 image was acquired on 3 September 2007, via a collaborative agreement with SPIRIT (Spot 5 stereoscopic survey of Polar Ice: Reference Images and Topographies; Korona and others, 2009).

\subsection{Image correction and data validation}

Fieldwork was conducted in July 2008 to collect ground control points (GCPs) to georectify and verify the air photographs, satellite imagery and DEMs. These GCPs were collected on distinctive rock nunataks and medial moraines with a Trimble R7 dGPS. The data were processed using the online Precise Point Positioning (PPP) service provided by Natural Resources Canada (http://www.geod.nrcan.gc.ca/ products-produits/ppp_e.php), which returned positions accurate to a few decimeters both horizontally and vertically. Alignment between the GCPs and 2007 SPOT-5 image was $\pm 10 \mathrm{~m}$ ( 2 pixels) horizontally, and therefore the SPOT-5 scene was used as a base image to georectify the other scenes in locations away from the GCPs.

For georectification, 20-70 tie points were selected across each satellite image in ESRI ArcGIS 9.2. The central moraine GCPs were used for $\sim 6$ tie points on average, while tie points on the SPOT-5 base image were selected based on recognizable features that were stationary in time and therefore not located on the ice or snow surface. An 'adjust' transformation was then applied, which optimizes local accuracy and the global least-square fitting by using polynomial transformation and triangular irregular network interpolation techniques depending on how well the image initially aligns with the GCPs (ESRI ArcGIS 9.2 Desktop Help). The rectified images were saved when visual investigation revealed pixel alignment of all major features within the area of interest and the RMSE was $<10 \mathrm{~m}$. For the air photographs, 35-80 points were selected for each photograph and a RMSE of $<10 \mathrm{~m}$ was deemed acceptable. The registered aerial photographs were mosaicked together to provide maximum coverage across the glacier.

Comparison of the 1977 CDED DEM with the digitized extent of the georectified 1977 Landsat image reveals an estimated horizontal error of \pm 1 pixel $(60 \mathrm{~m})$. This DEM was therefore not adjusted after its initial creation. The laser altimetry-derived DEMs did not require any warping or adjustment due to the use of dGPS for positioning during data acquisition. The accuracy of the ALTM data (collected in August 2007) was determined by comparing the surface elevation of 50 points with ground measurements made with the Trimble R7 dGPS (in July 2008) along a relatively flat portion of the medial moraine (Fig. 1). The mean difference 
Table 2. Area, height and volume changes of Kaskawulsh Glacier, 1977-2007

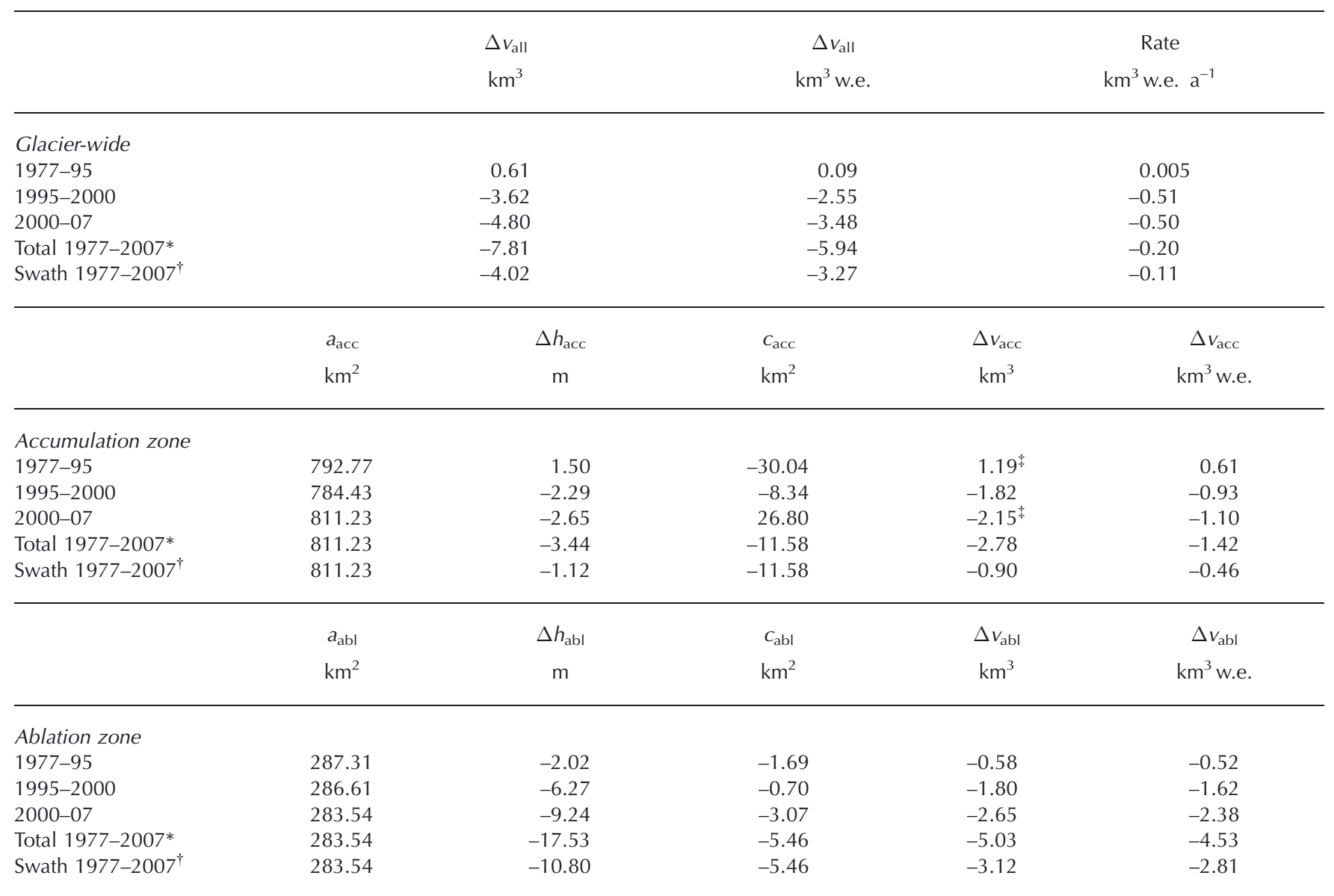

Note: See Equation (1) for details. a is area of remaining glacier ice; $\Delta h$ is change in height of remaining glacier ice; $c$ is change in area of the glacier. Ice density of $0.90 \mathrm{~g} \mathrm{~cm}^{-3}$ used to calculate water equivalent in ablation zone; snow density of $0.51 \mathrm{~g} \mathrm{~cm}^{-3}$ used in accumulation zone.

*Cumulative total of changes measured along the glacier centre-line profile between 1977-95, 1995-2000 and $2000-07$.

'Change measured across the glacier width using swath data from 1977 and 2007 only.

Calculated using the formula $\Delta v_{\mathrm{acc}}=\left(\mathrm{a}_{\mathrm{acc}} \Delta h_{\mathrm{acc}}\right)$; see section 2.5 for further details

between these measurements was $2.0 \mathrm{~m}$, with part of this likely due to unquantified interannual ice melt.

\subsection{Determination of changes in glacier extent}

The terminus position of Kaskawulsh Glacier was digitized for all area datasets, with measurements taken along 27 planes in the direction of ice flow to quantify its change in length over time. The difference in terminus area between images was also calculated. Most of the rest of the ablation area is bordered by steep valley side-walls that would show little change in glacier area even if there were substantial changes in ice thickness. Consequently, changes in glacier width in this region were deemed negligible and were excluded from area change analysis.

In the accumulation area, changes in extent were examined through changes in the area of five exposed rock nunataks. An effort was made to select rock complexes on each of the glacier arms to maximize representativeness of the findings across the accumulation zone. Furthermore, only images from summer and early fall were selected for analysis to reduce the impact of seasonal snowfall. A ratio between the area of the five rock complexes $\left(7.93 \mathrm{~km}^{2}\right)$ and the total exposed rock in the accumulation zone $\left(244.20 \mathrm{~km}^{2}\right)$ was calculated from the 1977 Landsat satellite imagery. This ratio was then used to produce an estimate of total change in rock area over time based on measurements at just the five rock complexes in later satellite images (Table 1). This method likely introduces errors in the area change estimates for the upper glacier, but still provides the best available areal data for this region in the absence of any ground control. Errors in the area change calculations can also arise from factors such as summer snowfall shortly before image acquisition, and from the image acquisition not coinciding with the minimum annual snow extent. Therefore, area changes for the accumulation area should be regarded as minimum estimates.

\subsection{Determination of changes in glacier height and volume}

The spatial distribution of absolute vertical surface-height changes along Kaskawulsh Glacier was derived by differencing the DEMs (Table 2). By combining these measurements with the area changes, the change in water equivalent ice volume for the entire glacier $\left(\Delta v_{\text {all }}\right)$ over a given time interval was calculated:

$$
\begin{aligned}
\Delta v_{\mathrm{all}}= & {\left[\left(\mathrm{a}_{\mathrm{acc}} \Delta h_{\mathrm{acc}}-C_{\mathrm{acc}} \Delta h_{\mathrm{acc}}\right) d_{\mathrm{acc}}\right] } \\
& +\left[\left(a_{\mathrm{abl}} \Delta h_{\mathrm{abl}}-c_{\mathrm{abl}} \Delta h_{\mathrm{abl}}\right) d_{\mathrm{abl}}\right],
\end{aligned}
$$

where $a$ is the area of remaining glacier ice, $\Delta h$ is the change in surface height, $c$ is the change in area of the glacier and $d$ is near-surface density. For $\Delta h$ and $c$, losses are indicated with negative values, and gains with positive 


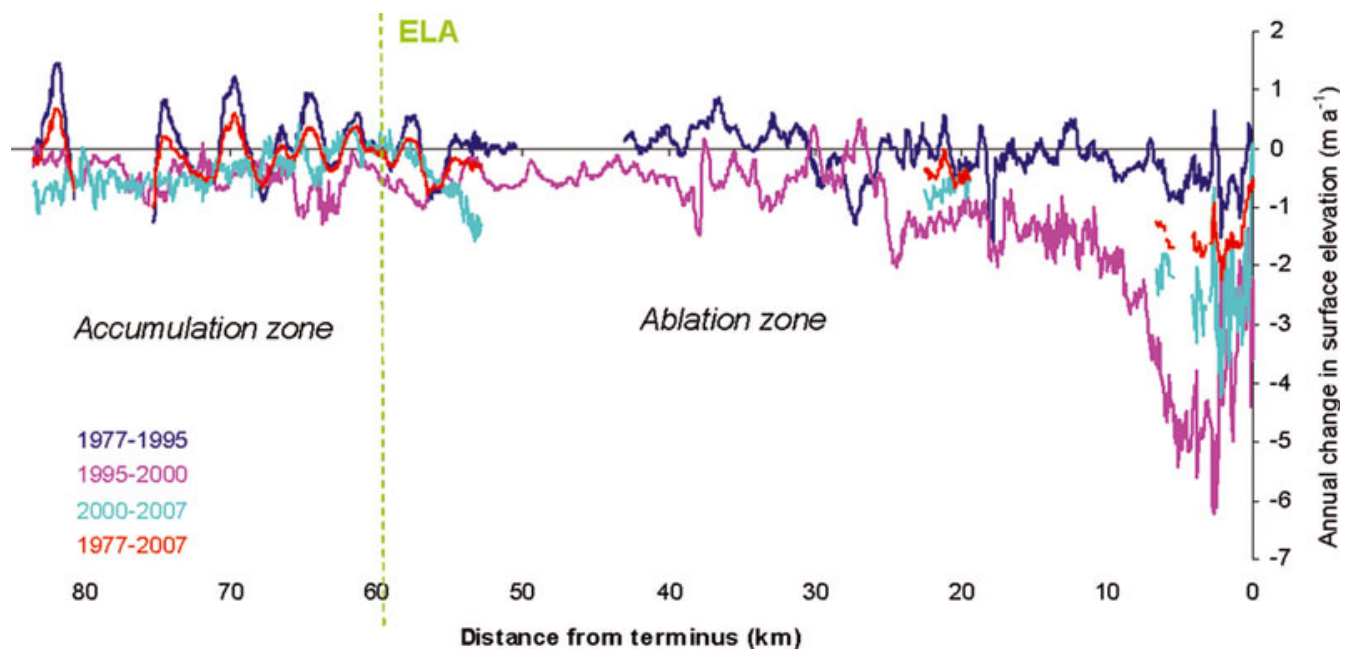

Fig. 2. Annual thinning/thickening along the central profile (shown in Fig. 1) for the periods 1977-95, 1995-2000, 2000-07 and $1977-2007$.

values. The subscript 'acc' represents values from the accumulation zone, while 'abl' represents values from the ablation zone. In certain cases, the change in height of the accumulation area is positive while the change in area is negative (or vice versa). In these cases the volume change accounted for by the change in area $\left(c_{\mathrm{acc}} \Delta h_{\mathrm{acc}}\right)$ is negligible and a value of 0 is used.

The ELA divides the accumulation and ablation zones and was determined from visual classification of the end-ofsummer snowline (ESS) from the 3 September 2007 SPOT image. This ESS occurred at $1958 \mathrm{~m}$, the highest over the 30 year period, although there was little variation observed in the earlier Landsat imagery (Table 1). Therefore an ELA of $1958 \mathrm{~m}$ is used throughout this study.

Densities in the accumulation zone were determined from snow samples taken at $10 \mathrm{~cm}$ increments in an $8.1 \mathrm{~m}$ deep snow pit dug at an elevation of $2606 \mathrm{~m}$ near the summit of Kaskawulsh Glacier in July $2007\left(60^{\circ} 40^{\prime} 44^{\prime \prime} \mathrm{N}\right.$, $139^{\circ} 47^{\prime} 44^{\prime \prime} \mathrm{W}$; Fig. 1). The mean density in this pit was $0.51 \mathrm{~g} \mathrm{~cm}^{-3}\left(d_{\mathrm{acc}}\right)$, with little variability with depth (std dev. $\left.0.11 \mathrm{~g} \mathrm{~cm}^{-3}\right)$. This depth is representative of the order of thickness changes observed, and was therefore used as a mean value for the accumulation area. Glacier ice dominates the ablation zone, so a density of $0.90 \mathrm{~g} \mathrm{~cm}^{-3}\left(d_{\mathrm{abl}}\right)$ was used for this area.

The change in volume of the glacier was calculated for the time intervals over which elevation data are available (1977-95, 1995-2000, 2000-07 and 1977-2007). These intervals are not exactly the same intervals over which data on changes in area are available (Table 1), so a linear rate of area change was assumed between known dates to adjust the area calculations.

\section{RESULTS}

\subsection{Changes in surface height by individual period for 1977-2007}

Changes in surface height along the centre line of the glacier over the period 1977-95 showed maximum thinning near the terminus (Table 2; Figs 2 and 3). Thinning is dominant throughout the ablation zone, although some areas of thickening (up to $1 \mathrm{~m} \mathrm{a}^{-1}$ ) do occur. For the entire length of the glacier the mean thinning was $1.0 \mathrm{~m}$ over the
18 year period, an average rate of $0.06 \mathrm{ma}^{-1}$. Within the ablation zone the average change was a thinning of $2.0 \mathrm{~m}$, while the mean change in the accumulation zone was a thickening of $1.5 \mathrm{~m}$.

Between 1995 and 2000, clear thinning of the glacier continued, with maximum losses of $31.1 \mathrm{~m}\left(6.2 \mathrm{~m} \mathrm{a}^{-1}\right)$ occurring near the terminus (Figs 2 and 3). There were a few small, isolated areas that appear to have thickened, although the localized nature of these changes suggests that they could be due to measurement error. For the ablation zone the mean change was a thinning of $6.3 \mathrm{~m}$, whereas in the accumulation zone there was a mean thinning of $2.3 \mathrm{~m}$. Overall, for the entire glacier length between 1995 and 2000 the mean thinning was $6.0 \mathrm{~m}$, or $1.2 \mathrm{~m} \mathrm{a}^{-1}$.

Between 2000 and 2007, thinning continued at a reduced rate (Figs 2 and 3). The terminus underwent an average thinning of $9.2 \mathrm{~m}\left(1.3 \mathrm{~m} \mathrm{a}^{-1}\right)$, with maximum thinning in excess of $29 \mathrm{~m}\left(4.1 \mathrm{~m} \mathrm{a}^{-1}\right)$. In the accumulation zone, average thinning of $2.7 \mathrm{~m}$ was observed. The average thinning for the glacier centre line as a whole was $4.8 \mathrm{~m}$, a rate of $0.7 \mathrm{~m} \mathrm{a}^{-1}$.

\subsection{Overall changes in surface height for 1977-2007}

Due to the fact that the 1977 DEM covers the entire Kaskawulsh Glacier and the 2007 DEM was created using swath mapping, a greater area of the glacier can be compared for thickness change by comparing these datasets than by plotting centre-line changes for the individual periods. Using this increased coverage, the ablation zone thinned by an average of $10.8 \mathrm{~m}$ between 1977 and 2007 $\left(0.36 \mathrm{~m} \mathrm{a}^{-1}\right.$; Table 2 ; Figs 2 and 3$)$. Thinning was particularly extensive across the glacier terminus, with maximum losses (up to $88 \mathrm{~m}$ ) near the glacier centre. The accumulation zone underwent modest overall thinning of $1.1 \mathrm{~m}$, although some areas did experience localized thickening. Overall the mean thinning of Kaskawulsh Glacier between 1977 and 2007 is $6.1 \mathrm{~m}$, which equates to $0.20 \mathrm{~m} \mathrm{a}^{-1}$.

When the thickness changes from the individual periods 1977-95, 1995-2000 and 2000-07 are added together, the accumulation area is shown to have thinned by an average of $3.44 \mathrm{~m}$, and the ablation area by an average of $17.53 \mathrm{~m}$ (Table 2; Figs 2 and 3). This produces an overall thinning of the glacier of $13.80 \mathrm{~m}\left(0.46 \mathrm{~m} \mathrm{a}^{-1}\right)$. These values differ somewhat from the $0.20 \mathrm{~m} \mathrm{a}^{-1}$ thinning measured directly from 1977 to 2007, because narrow centre-line profiles 

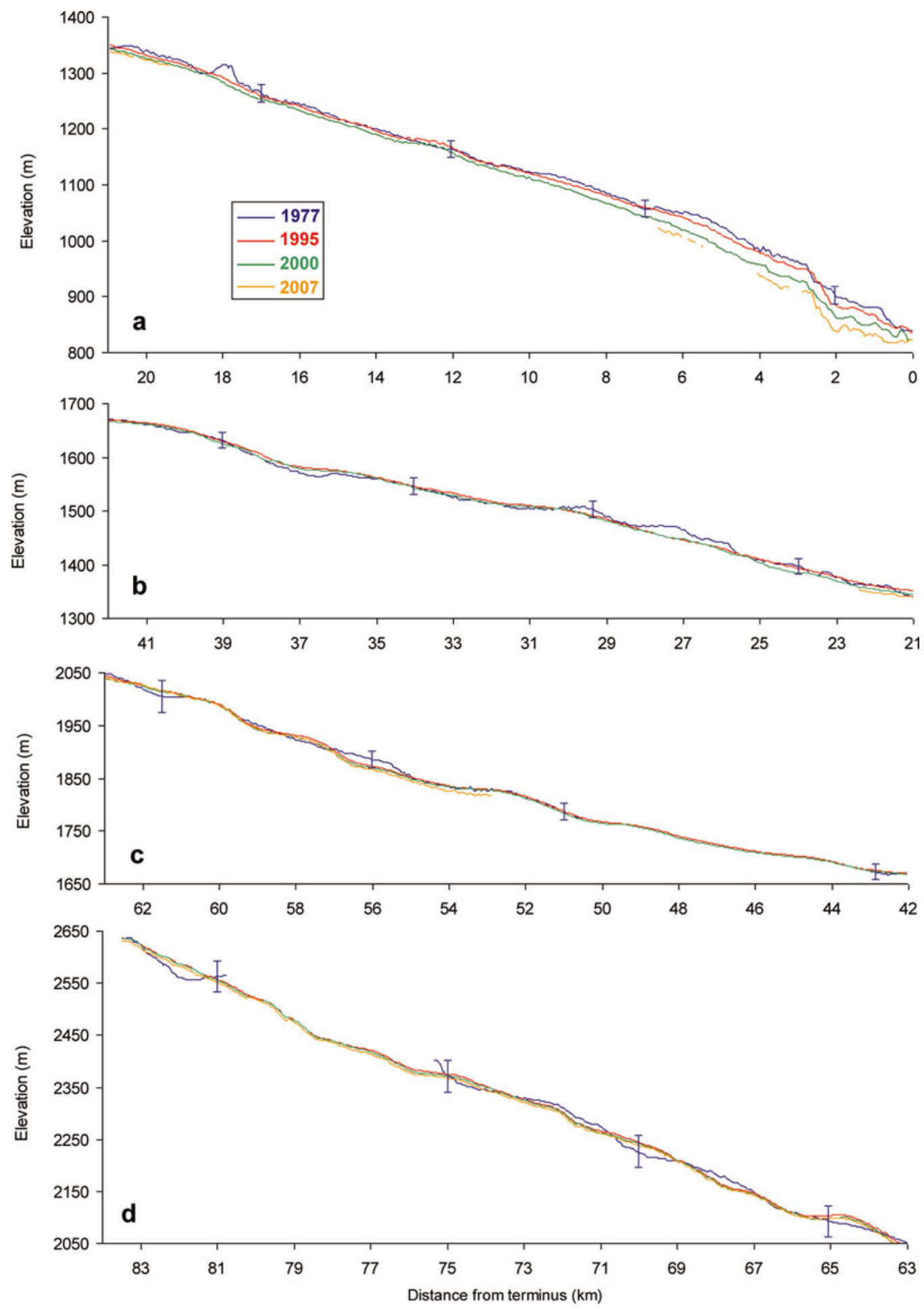

Fig. 3. Elevation profile along the centre line of Kaskawulsh Glacier (purple line in Fig. 1) for 1977, 1995, 2000 and 2007 for (a) terminus, (b) lower ablation zone, (c) upper ablation zone and (d) accumulation zone. Error bars shown for 1977 ( $\pm 15 \mathrm{~m}$ in ablation zone, $\pm 30 \mathrm{~m}$ in accumulation zone); error bars too small to be shown for 1995 ( $\pm 0.3 \mathrm{~m}), 2000$ ( $\pm 0.3 \mathrm{~m})$ or 2007 ( $\pm 0.5 \mathrm{~m})$.

neglect differential thinning across the glacier width. Because the changes in thickness at the glacier centre are assumed to be constant across the glacier width for the periods 1977-95, 1995-2000 and 2000-07, between 1 and $3 \mathrm{~m} \mathrm{a}^{-1}$ of vertical error at the glacier margins may have been introduced, with errors likely greatest at low elevations (Echelmeyer and others, 1996; Arendt and others, 2008). Barrand and others (2010) discuss this issue in detail, and conclude that significant differences in mass-balance estimates may occur between centre-line and full-glacier surveys due to the high complexity of surface height changes within elevation bands. The error introduced by ignoring this non-uniformity cannot be quantified in this study due to data only being available from centre-line surveys in 1995 and 2000, although Figure 4 illustrates the variability in ice loss that occurs across the glacier width when comparing the 1977 and 2007 surveys directly. To address this limitation we calculated ice losses using both methods, and use these to bracket the likely range of mass losses over the study period. 

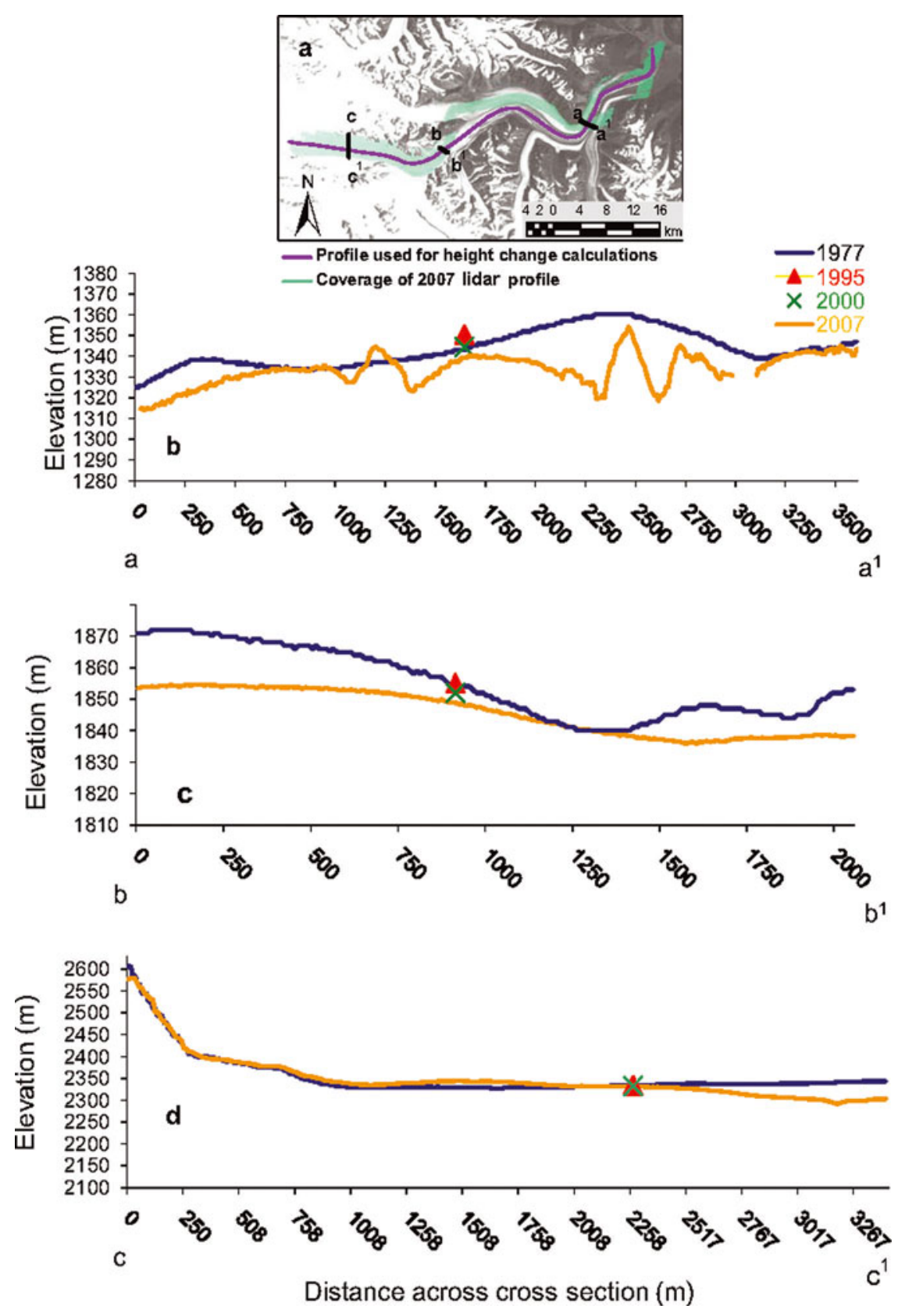

Fig. 4. (a) Location of sampled cross sections; (b) cross section at $1340 \mathrm{~m}\left(\mathrm{a}_{-} \mathrm{a}^{1}\right)$; (c) cross section at $1850 \mathrm{~m}\left(\mathrm{~b}-\mathrm{b}^{1}\right)$; (d) cross section at $2330 \mathrm{~m}\left(\mathrm{c}-\mathrm{c}^{1}\right)$.

\subsection{Changes in area}

Figure 5 shows the changes in terminus position of Kaskawulsh Glacier between 1956 and 2007, with the details provided in Table 3. Over this period the glacier retreated by an average of $655 \mathrm{~m}$, with a decrease in terminus area of $8.20 \mathrm{~km}^{2}$. Over the entire 51 year period, there was only one brief interval of readvance, between 1986 and 1990, when the terminus moved forward by $62 \mathrm{~m}$, resulting in an increase in terminus area of $0.54 \mathrm{~km}^{2}$. The greatest rate of retreat occurred in 2006/07, when the glacier receded $79 \mathrm{ma}^{-1}$, resulting in a terminus area loss of $0.87 \mathrm{~km}^{2}$. This was accommodated largely by the expansion of terminal lakes on the eastern and western lobes. Over the period 1977-2007, glacier retreat amounted to $471 \mathrm{~m}$, accounting for an area loss of $5.46 \mathrm{~km}^{2}$.

The rate of area change in the accumulation zone has varied over time (Fig. 6). By extrapolating the changes in the
Table 3. Change in terminus position of Kaskawulsh Glacier, 1956-2007

\begin{tabular}{lccc}
\hline & $\begin{array}{c}\text { Average change in } \\
\text { position } \\
\mathrm{m}\end{array}$ & $\begin{array}{c}\text { Average rate of } \\
\text { change in position } \\
\mathrm{m} \mathrm{a}^{-1}\end{array}$ & $\begin{array}{c}\text { Change in } \\
\text { terminus area } \\
\mathrm{km}^{2}\end{array}$ \\
\hline $1956-77$ & -184 & -9 & -2.74 \\
$1977-86$ & -134 & -15 & -1.82 \\
$1986-90$ & 62 & 16 & 0.54 \\
$1990-94$ & -41 & -10 & -0.24 \\
$1994-2001$ & -87 & -12 & -1.05 \\
$2001-03$ & -32 & -16 & -0.66 \\
2003-06 & -146 & -49 & -1.36 \\
$2006-07$ & -79 & -79 & -0.87 \\
$1956-2007$ & -655 & -13 & -8.20 \\
\end{tabular}




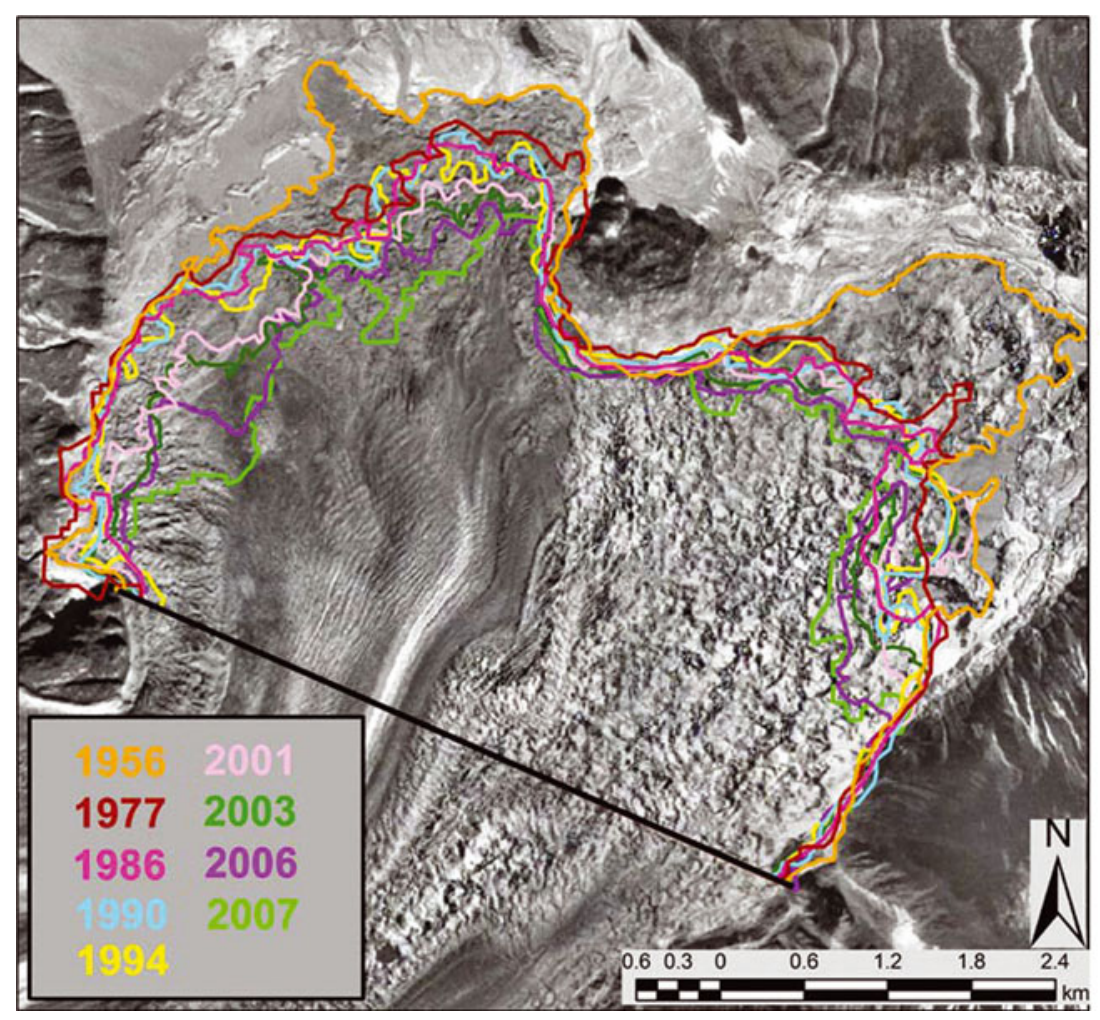

Fig. 5. Temporal variations in terminus position of Kaskawulsh Glacier displayed over a 1956 air photograph.

five representative nunatak complexes across the entire accumulation zone, an estimated increase in exposed rock of $40.05 \mathrm{~km}^{2}$ occurred between 1977 and 2001, while the area of exposed rock decreased by $28.47 \mathrm{~km}^{2}$ between 2001 and 2007. Thus, between 1977 and 2007 there was an overall ice loss of $11.58 \mathrm{~km}^{2}$, which equates to an ice area decrease of

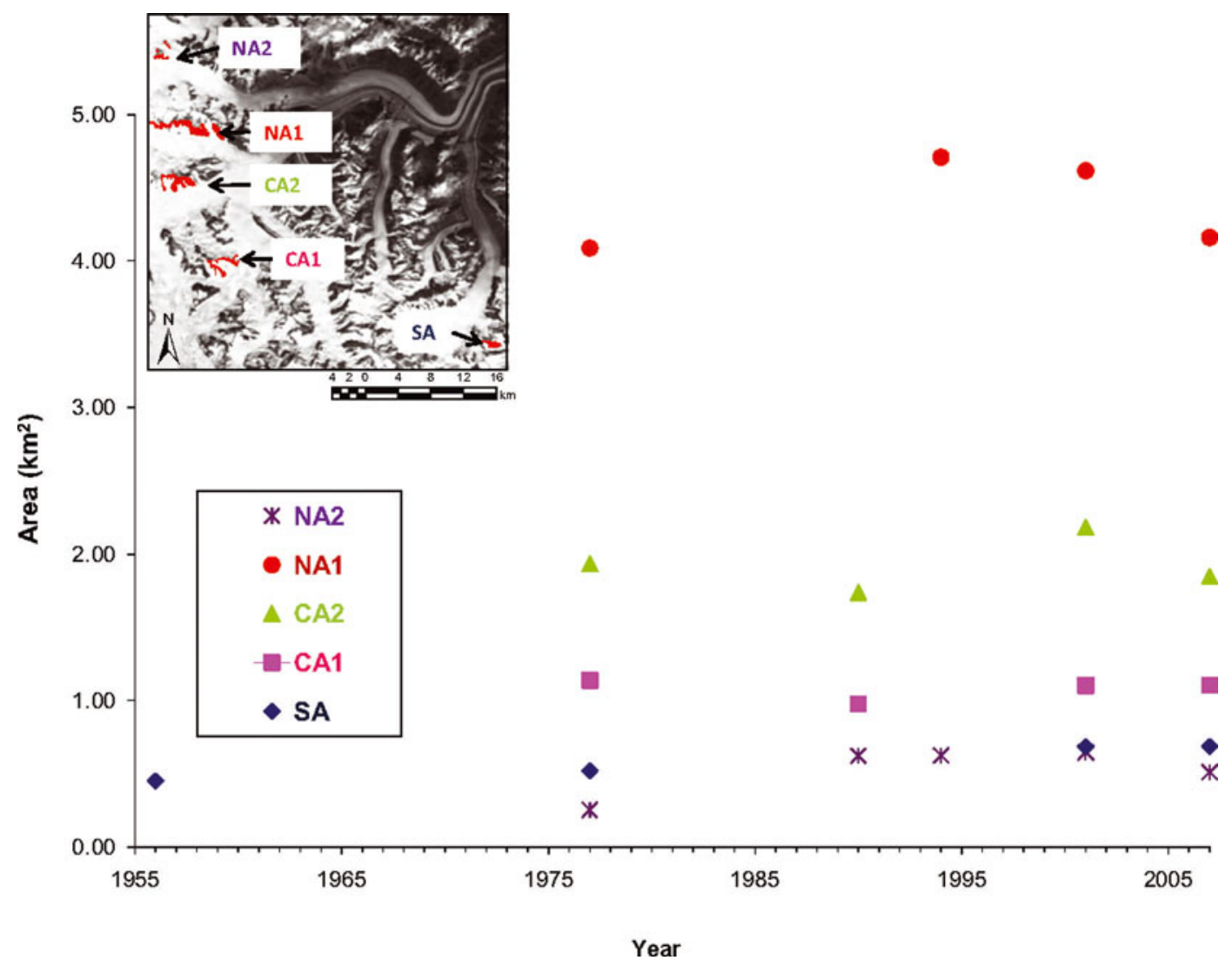

Fig. 6. Area changes over time of nunataks across the accumulation area of Kaskawulsh Glacier. NA represents exposed rock complexes on the northern arm of the glacier, CA the central arm and SA the southern arm. 


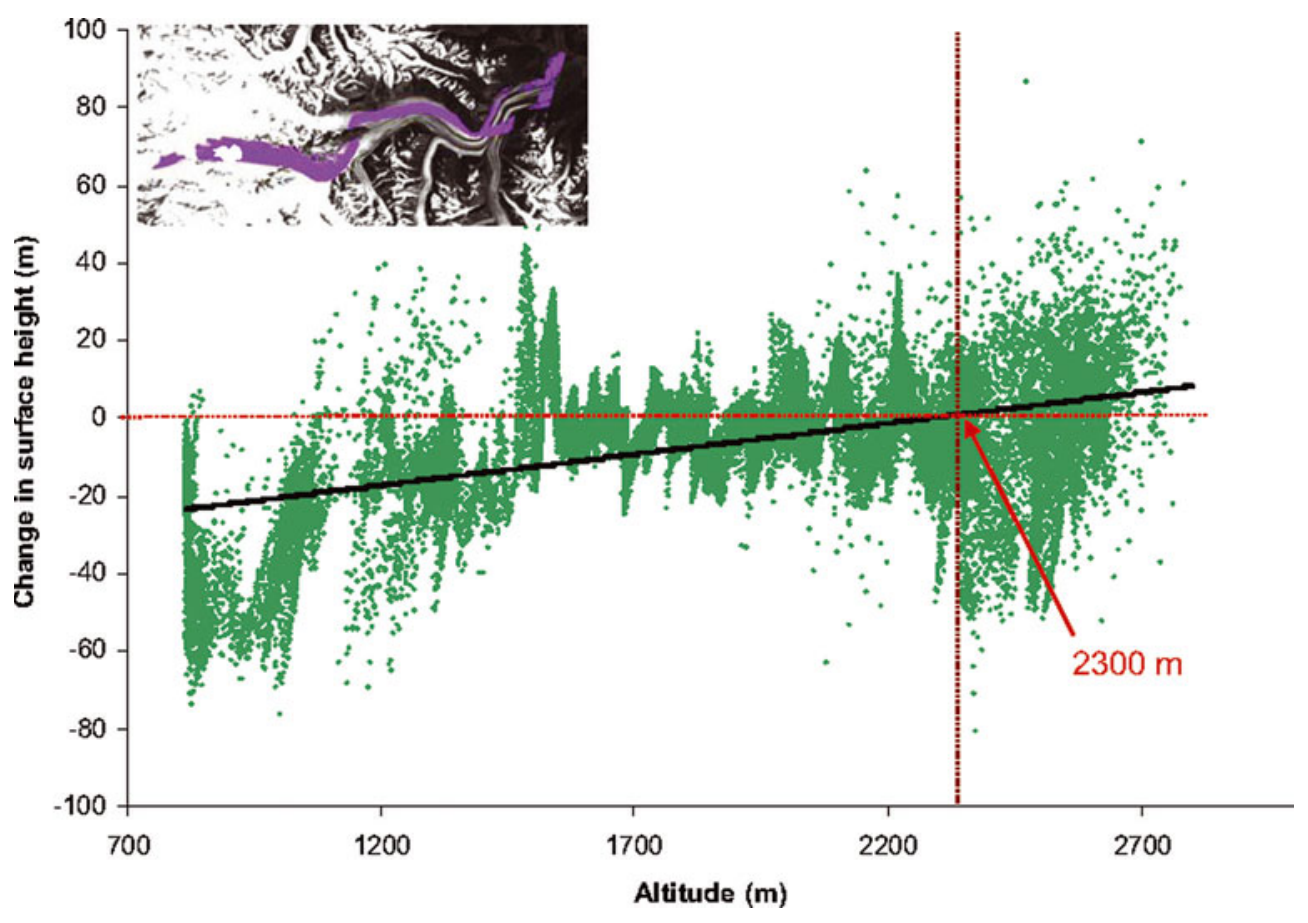

Fig. 7. Relationship between changes in surface height and altitude for 1977-2007 along the swath profile shown in inset map.

$0.39 \mathrm{~km}^{2} \mathrm{a}^{-1}\left(0.05 \% \mathrm{a}^{-1}\right)$. Variability in snow accumulation and melt patterns across the accumulation zone of the glacier appears to be relatively low as fluctuations are relatively uniform across all nunatak complexes.

In 1977, the area of the glacier as a whole was $1111.81 \mathrm{~km}^{2}$. In 2001, the area had decreased to $1069.24 \mathrm{~km}^{2}$. By 2007, the glacier had increased in area by $25.55 \mathrm{~km}^{2}$, to $1094.79 \mathrm{~km}^{2}$, largely due to increases in the accumulation area. Therefore, over the 30 year period, the glacier decreased in area by $17.02 \mathrm{~km}^{2}$, or $1.53 \%$.

\subsection{Changes in volume}

The total reduction in water equivalent volume of Kaskawulsh Glacier, calculated by summing the centre-line data from the separate measurement intervals and using the appropriate densities from the accumulation and ablation zones, is a decrease of $5.94 \mathrm{~km}^{3}$ w.e. $\left(-0.20 \mathrm{~km}^{3}\right.$ w.e. $\left.\mathrm{a}^{-1}\right)$ between 1977 and 2007 (Table 2). Losses in volume occurred prominently in the ablation zone $\left(-4.53 \mathrm{~km}^{3}\right.$ w.e. $)$, and more moderately in the accumulation zone $\left(-1.42 \mathrm{~km}^{3}\right.$ w.e.).

Volume change was also calculated directly from the overall area changes between 1977 and 2007, and the overall surface height changes between the 1977 DEM and the full $2.3 \mathrm{~km}$ wide swath DEM from 2007. These data show that between 1977 and 2007 the glacier lost a total of $3.27 \mathrm{~km}^{3}$ w.e., at an overall rate of $-0.11 \mathrm{~km}^{3}$ w.e. $\mathrm{a}^{-1}$. There were small volume losses in the accumulation zone $\left(-0.46 \mathrm{~km}^{3}\right.$ w.e. $)$, and moderate volume losses in the ablation zone $\left(-2.81 \mathrm{~km}^{3}\right.$ w.e.). Any inaccuracy in estimation of the ELA will affect calculated volume losses as different density values are associated with the ablation and accumulation zones, although the effect of this error will be minimal given the total volume change. Changes in volume cannot be directly interpreted as changes in mass balance, however, as at least some of the volume change could be attributed to internal accumulation, particularly in the accumulation zone. Although difficult to quantify, internal accumulation can account for $5-100 \%$ of annual net accumulation (Kaser and others, 2006).

\section{DISCUSSION AND CONCLUSION}

Our results clearly indicate that Kaskawulsh Glacier has lost mass over the period 1977-2007, with average overall thinning of $0.20-0.46 \mathrm{~m} \mathrm{a}^{-1}$ and a decrease in overall volume of $3.27-5.94 \mathrm{~km}^{3}$ w.e. These changes have largely occurred as a function of changes in surface height, rather than area. These changes are also variable with altitude; negative changes have been prominent in the ablation zone (average thinning $0.4-0.5 \mathrm{mw} . e . \mathrm{a}^{-1}$ ), but minimal in the accumulation zone (average thinning $0.04-0.11 \mathrm{~m} \mathrm{a}^{-1}$ ) (Fig. 7). At $2300 \mathrm{~m}$ a.s.l., net change in surface height is zero, with net gains above this altitude over the period 1977-2007 (although the deviation about this trend is large). This is consistent with surface height changes on other glaciers in this region, which have demonstrated slight to no thinning at higher elevations, and increasingly prominent thinning towards the glacier terminus (Arendt and others, 2006; Molnia 2007). For example, Arendt and others (2006) found that at least 23 glaciers in the western Chugach Mountains displayed this pattern of surface height change between the 1950s and the early 2000s.

The glacier reductions reported in this paper and by Barrand and Sharp (2010) are in step with observed decadal warming trends in interior Alaska and northwestern Canada (Stafford and others, 2000; Environment Canada, http://www. ec.gc.ca/adsc-cmda/default.asp?lang=en $\& n=4 C C 724 D A-1$ ). The impact of such massive glacier changes is particularly significant for watersheds such as that of the Yukon River, where perennial ice and snow cover, while only accounting for $\sim 1 \%$ of the total catchment area, play a major role in regulating discharge year-round. Already, glacier losses have altered the hydrological regime of rivers from Alberta to Alaska (Demuth and others, 2008; Janowicz, 2008; Moore 


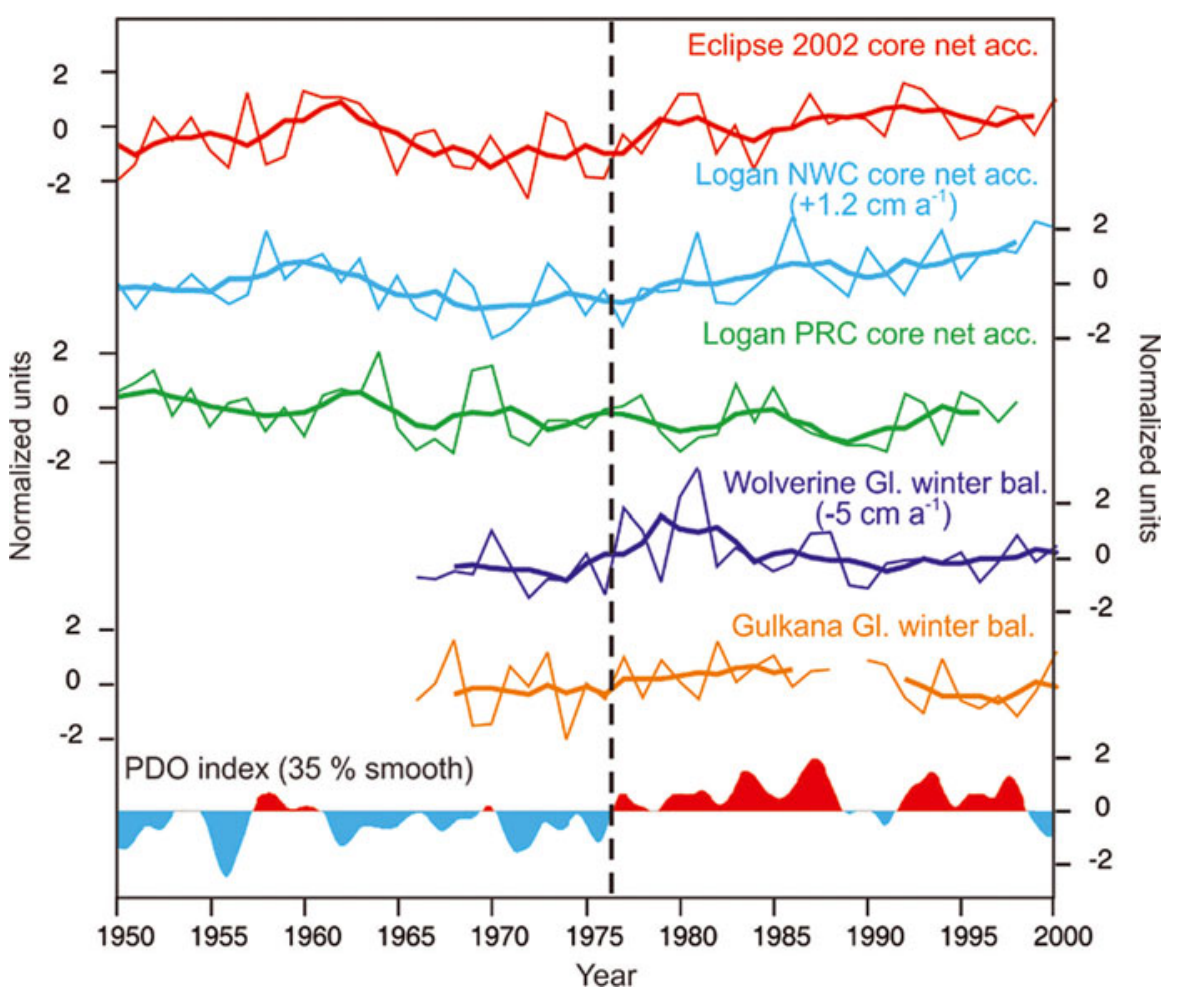

Fig. 8. Historical variations in snow accumulation, 1950-2000, reconstructed from ice cores drilled in the Mount Logan area of the St Elias Mountains, and from winter balance measurements on two southeastern Alaska glaciers (Wolverine and Gulkana). Mount Logan ice cores: NWC $=$ Northwest Col; PRC $=$ Prospector-Russell Col. Thin curves denote annual variations, bold curves are 5 year running averages. The data were normalized to ease comparison. The PDO index for 1950-2000 is shown for comparison (data from Joint Institute for the Study of the Atmosphere and Ocean, University of Washington). The vertical line highlights the 1976 PDO modal shift. Of all the accumulation series shown, only two (Logan NWC and Wolverine Glacier) have post-1976 trends that are statistically significant ( $p=0.05$; trends shown in parentheses).

and others, 2009). What remains uncertain, however, is whether the recent warming is accompanied by increases in accumulation on the glacerized regions of Alaska and the Yukon.

There exist no long-term (>10 year) instrumental records of precipitation from the St Elias or Wrangell Mountains. However, reconstructions of historical snowfall have been developed from winter balance (accumulation) measurements on southeastern Alaskan glaciers, and from ice cores drilled on or near Mount Logan $\left(60^{\circ} 35^{\prime} \mathrm{N}, 140^{\circ} 30^{\prime} \mathrm{W}\right.$; 5300 m a.s.l.) in the central St Elias Mountains (Fig. 8). The winter balance of the maritime Wolverine and Gulkana Glaciers, southeast Alaska, is influenced by the Pacific Decadal Oscillation (PDO; Hartmann and Wedler 2005), and Wolverine Glacier experienced an increase in winter accumulation after the 1976 PDO modal shift (Hodge and others, 1998). However, since 1989 both glaciers have had sustained negative net balance trends, with summer melt losses surpassing winter nourishment (Josberger and others, 2007). In the southern Yukon, Moore and others (2002) reported a positive trend in snow accumulation of $1.2 \mathrm{~cm}$ w.e. $\mathrm{a}^{-1}$ over the period 1976-91 using a composite record of cores from Northwest Col (NWC) on Mount Logan. However, a separate core, drilled in 2001/02 from nearby Prospector-Russell Col (PRC; $5340 \mathrm{~m}$ a.s.I.; Fisher and others, 2008), also on Mount Logan, shows no such trend over the same period (Fig. 8). Meanwhile, cores drilled in 1996 and 2002 from the Eclipse Icefield $\left(60^{\circ} 51^{\prime} \mathrm{N}\right.$, $139^{\circ} 47^{\prime} \mathrm{W}$; $3017 \mathrm{~m}$ a.s.I.), $45 \mathrm{~km}$ northeast of Kaskawulsh Glacier's summit area (Wake and others, 2002), show post-1976 trends of 2.5 and $1.1 \mathrm{~cm} \mathrm{a}^{-1}$, respectively, but neither trend is statistically significant $(p=0.05)$. The trend in the stacked 1996+2002 Eclipse record is only $0.04 \mathrm{~cm} \mathrm{a}^{-1}$. Elsewhere, Yasunari and others (2007) reported on a 10 year ice-core record from Mount Wrangell, Alaska, $\left(62^{\circ} \mathrm{N}\right.$, $144^{\circ} \mathrm{W} ; 4100 \mathrm{ma.s.l}$.) which appears to lack any clear accumulation trend. Finally, a >500 year long record of accumulation was developed from a core drilled on Mount Bona-Churchill, Alaska $\left(61^{\circ} 24^{\prime} \mathrm{N}, 42^{\circ} 00^{\prime} \mathrm{W}\right.$; 4420 m a.s.l. $)$ (Urmann, 2009), but its significance is yet to be tested.

In summary, evidence for increasing snowfall in the central St Elias Mountains over the period of interest (post1976) remains ambiguous. In the absence of such evidence, it must be anticipated that the mass balance of glaciers in the region will continue to become increasingly negative in the foreseeable future, with melt-induced losses far exceeding snowfall nourishment. Regional impact assessments on hydrological consequences should take this into consideration.

\section{ACKNOWLEDGEMENTS}

We thank the Canadian Foundation for Innovation (CFI), Ontario Research Fund (ORF), Natural Sciences and Engineering Research Council of Canada (NSERC), Northern Scientific Training Program (NSTP), University of Ottawa and Parks Canada for financial and logistical support. We also thank the Arctic Institute of North America, C. Wong and S. Pope for contributions to fieldwork. SPOT-5 data access was provided by the SPIRIT project. Special thanks to 
K. Echelmeyer, A. Arendt and the University of Alaska Fairbanks for supplying data. Research students from the Applied Geomatics Research Group are acknowledged for assisting with lidar data collection activities. Lidar data collection was facilitated by the Canadian Consortium for Lidar Environmental Applications Research (C-CLEAR) and a funding grant to M.N.D. and C.H. from the Canadian Space Agency. This is Natural Resources Canada Earth Sciences Sector (ESS) contribution 20100139.

\section{REFERENCES}

Arctic Climate Impact Assessment (ACIA). 2004. Impact of a warming Arctic. Cambridge, etc., Cambridge University Press.

Arendt, A.A., K.A. Echelmeyer, W.D. Harrison, C.S. Lingle and V.B. Valentine. 2002. Rapid wastage of Alaska glaciers and their contribution to rising sea level. Science, 297(5580), 382-386.

Arendt, A. and 7 others. 2006. Updated estimates of glacier volume changes in the western Chugach Mountains, Alaska, and a comparison of regional extrapolation methods. J. Geophys. Res., 111(F3), F03019. (10.1029/2005JF000436.)

Arendt, A.A., S.B. Luthcke, C.F. Larsen, W. Abdalati, W.B. Krabill and M.J. Beedle. 2008. Validation of high-resolution GRACE mascon estimates of glacier mass changes in the St Elias Mountains, Alaska, USA, using aircraft laser altimetry. J. Glaciol., 54(188), 778-787.

Barrand, N.E. and M.J. Sharp. 2010. Sustained rapid shrinkage of Yukon glaciers since the 1957-1958 International Geophysical Year. Geophys. Res. Lett., 37(L7), L07051. (10.1029/ 2009GL042030.)

Barrand, N.E., T.D. James and T. Murray. 2010. Spatiotemporal variability in elevation changes of two high-Arctic valley glaciers. J. Glaciol., 56(199), 771-780.

Borns, H.W. and R.P. Goldthwait. 1966. Late-Pleistocene fluctuations of Kaskawulsh Glacier, SW Yukon Territory, Canada. Am. J. Sci., 264(8), 600-619.

Chen, J.L., B.D. Tapley and C.R. Wilson. 2006. Alaskan mountain glacial melting observed by satellite gravimetry. Earth Planet. Sci. Lett., 248(1-2), 368-378.

Demuth, M.N. and 6 others. 2008. Recent and past-century variations in the glacier resources of the Canadian Rocky Mountains-Nelson River system. Terra Glacialis, 11(248), 27-52.

Echelmeyer, K.A. and 8 others. 1996. Airborne surface profiling of glaciers: a case-study in Alaska. J. Glaciol., 42(142), 538-547.

Fisher, D. and 16 others. 2008. The Mt Logan Holocene-late Wisconsinan isotope record: tropical Pacific-Yukon connections. Holocene, 18(5), 667-677.

Goulden, T. and C. Hopkinson. 2010. The forward propagation of integrated system component errors within airborne LIDAR data. Photogramm. Eng. Remote Sens., 76(5), 589-601.

Hartmann, B. and G. Wendler. 2005. The significance of the 1976 Pacific climate shift in the climatology of Alaska. J. Climate, 18(22), 4824-4839.

Hodge, S.M., D.C. Trabant, R.M. Krimmel, T.A. Heinrichs, R.S. March and E.G. Josberger. 1998. Climate variations and changes in mass of three glaciers in western North America. J. Climate, 11(9), 2161-2179.

Hopkinson, C. and M.N. Demuth. 2006. Using airborne lidar to assess the influence of glacier downwasting on water resources in the Canadian Rocky Mountains. Can. J. Remote Sens., 32(2), 212-222.
Hopkinson, C., M. Demuth, M. Sitar and L. Chasmer. 2001. Applications of airborne LiDAR mapping in glacierised mountainous terrain. In IGARSS '01. 21st International Geoscience and Remote Sensing Symposium, 9-13 July 2001, Sydney, Australia. Proceedings, Vol. 2. Piscataway, NJ, Institute of Electrical and Electronics Engineers, 949-951.

Janowicz, J.R. 2008. Apparent recent trends in hydrologic response in permafrost regions of northwest Canada. Hydrol. Res., 39(4), $267-275$.

Josberger, E.G., W.R. Bidlake, R.S. March and B.W. Kennedy. 2007. Glacier mass-balance fluctuations in the Pacific Northwest and Alaska, USA. Ann. Glaciol., 46, 291-296.

Kaser, G., J.G. Cogley, M.B. Dyurgerov, M.F. Meier and A. Ohmura. 2006. Mass balance of glaciers and ice caps: consensus estimates for 1961-2004. Geophys. Res. Lett., 33(19), L19501. (10.1029/2006GL027511.)

Korona, J., E. Berthier, M. Bernard, F. Rémy and E. Thouvenot. 2009. SPIRIT. SPOT 5 stereoscopic survey of Polar Ice: Reference Images and Topographies during the fourth International Polar Year (2007-2009). ISPRS J. Photogramm. Rem. Sens, 64(2), 204-212.

Larsen, C.F., R.J. Motyka, A.A. Arendt, K.A. Echelmeyer and P.E. Geissler. 2007. Glacier changes in southeast Alaska and northwest British Columbia and contribution to sea level rise. J. Geophys. Res., 112(F1), F01007. (10.1029/2006JF000586.)

Luthcke, S.B., A.A. Arendt, D.D. Rowlands, J.J. McCarthy and C.F. Larsen. 2008. Recent glacier mass changes in the Gulf of Alaska region from GRACE mascon solutions. J. Glaciol., 54(188), 767-777.

Molnia, B.F. 2007. Late nineteenth to early twenty-first century behavior of Alaskan glaciers as indicators of changing regional climate. Global Planet. Change, 56(1-2), 23-56.

Moore, G.W.K., G. Holdsworth and K. Alverson. 2002. Climate change in the North Pacific region over the past three centuries. Nature, 420(6914), 401-403.

Moore, R.D. and 7 others. 2009. Glacier change in western North America: influences on hydrology, geomorphic hazards and water quality. Hydrol. Process., 23(1), 42-61.

Reyes, A.V., B.H. Luckman, D.J. Smith, J.J. Clague and R.D. van Dorp. 2006. Tree-ring dates for the maximum Little Ice Age advance of Kaskawulsh Glacier, St. Elias Mountains, Canada. Arctic, 59(1), 14-20.

Solomon, S. and 7 others, eds. 2007. Climate change 2007: the physical science basis. Contribution of Working Group I to the Fourth Assessment Report of the Intergovernmental Panel on Climate Change. Cambridge, etc., Cambridge University Press.

Stafford, J., G. Wendler and J. Curtis. 2000. Temperature and precipitation of Alaska: 50 year trend analysis. Theor. Appl. Climatol., 67(1-2), 33-44.

Urmann, D. 2009. Decadal scale climate variability during the last millennium as recorded by the Bona-Churchill and Quelccaya ice cores. (PhD thesis, The University of Ohio.)

Wake, C.P., K. Yalcin and N.S. Gundestrup. 2002. The climate signal recorded in the oxygen-isotope, accumulation and majorion time series from the Eclipse ice core, Yukon Territory, Canada. Ann. Glaciol., 35, 416-422.

Wiles, G.C., G.C. Jacoby, N.K. Davi and R.P. McAllister. 2002. Late Holocene glacier fluctuations in the Wrangell Mountains, Alaska. Geol. Soc. Am. Bull., 114(7), 896-908.

Yasunari, T.J. and 7 others. 2007. Intra-annual variations in atmospheric dust and tritium in the North Pacific region detected from an ice core from Mount Wrangell, Alaska. J. Geophys. Res., 112(D10), D10208. (10.1029/2006JD008121.) 